\title{
Ethnobotany of the Ficus Benglensis
}

\author{
Teena Agrawal* \\ Banasthali University, India
}

Submission: January 19, 2018; Published: February 12, 2018

"Corresponding author: Teena Agrawal, Assistant professor, Banasthali University, Niwai, India, Email: tagrawal02@gmail.com

\section{Abstract}

Plants are the reservoirs of the many kinds of the metabolites of the various significance, they are used by the civilization from the remote past. Traditional medicines are the medicines which are used by the communities for the treatment of the various kinds of the diseases. They are the resultant of the various civilization experiences which are living in the vicinity of the nature from the long time. WHO promotes the strategy for the saving of the plants and the other TM and the ACM for the primary health care of the peoples. In this review articles we are presenting some of the aspects of the tree entitled as the Ficus bengalensis of the Moraceae family. The plant is widely distributed in the India as well as the other part of the world. In the Hindu religion the tree is worshipped and they are used in many days for the ethical purposes.

In conventional medicines the tree is used for the treatment of them any kinds of the diseases, so it has been investigated as the photochemical as well as the pharmacological aspects, in addition to that the plant has been worked out by many ways. However the tree canopy occupies the whole area and it needs the conservation.

Keywords: Ficus bengaenlsis; Photochemistry; medicinal plants; Worshipped; TM; ACM

\section{Introduction}

Medicinal plants are the reservoirs of the many kinds of the metabolites of the medicinal significances, they are utilised for the various purposes from the many civilizations. From the times of the Greek and the Egypt they are utilization for the treatment of the many diseases. Traditional medicines are the medicines which are utilised by the countries on the basis of the folk medicines and the experiences of the communities by the continuous exposure to the ecosystem or the cultures.

WHO states that the about the 80 percent of the population on the world still depend on the herbal plants for the primary health care or for the medicines. Since theses medicines are the cheap and easy to uses and the side effects of the medicines are very less. The chemical drugs in addition are very costly and they have the tremendous side effects. So still today in that world the peoples relies on the herbs for the treatment of the diseases.

Chinese's herbal medicines, ayuerveidc herbal medicines, uanani herbalmedicines and the siddha medicines and the medicines the other parts of the world still depend on the utilization of the herbal drugs for the treatment of the many kinds of the diseases.

Here in this review article we are presenting some of the aspects of the herb entitled as Ficus bengelaensis, the tree is the member of the Moracae family. The tree is the evergreen and the tree is commonly known as the Indian banyan tree. The banyan tree is famous for the many kinds of the ritual and the mythological values and the terms.
The banyan tree is found to be the place of the many god, goddess like the lord Shiva and the lord Vishnu. The Ficus benalgensis is suppose to be the Indian national tree $[1,2]$. Banyan tree is native of the India as well as south East Asia, especially in the Pakisthan; the tree is often planted near the temple and the other places where religion is very much. It grows in to the tropical as well as the subtropical part of the world. The annual rainfall ranges from the $100 \mathrm{~cm}$ to the higher. Humid air, moist soil and the other climatic conditions are needed for the successful survival of the tree [3-5].

Morphology of the tree: Banyan is the homogonous tree with branches spreading across the whole tree. The tree attains the height of the more than 100 meters or the 150 meters [1,2]. The massive limbs are supported by the prop roots ,theses props roots are the way of maintaining the balance of the tree .its bark is smooth ,green and dark, leaves are glossy ,leathery ,when mature the leaves become very leather ,they are green and the ovate ,the margin are entire and the smooth $[6,7]$.

Flowers are the typical Moracaeous family, they have the hypenthodium, the male and the female flower are arrange the suture of the fruit and the type of the pollination is like the typical of the Moraceae type [1-3,5].

Fruit are the typical of the fleshy, they have the globes appearances. The fruit has the fleshy cremocarp and they are not eaten by the human but they are eaten by the animal and the birds. 


\section{Phytochemistry}

Many workers have worked on the different aspects of the photochemistry and they found the profound results. However some of the result are summarises here as. Stem bark consist of the many kinds of the anthocyanindins such as the aliphatic long chain acids, ketones bodies such as beta sitosterol, glycosides, mesoinositol [8].

The leaves contain the 9.63 percent crude proteins, 26.84 crude fibres, 2.53 calcium oxalate, 4 percent phosphorus. By the number of the qultaitve tests the leaves are come to know the following kinds of the pigments these are enumerated as the flavenoids, saponin, tannins, phenol, and other terpenoids.

Pharmacological aspects the plant has been worked out extensively, and it has been found that these are the some of the pharmacological activity which has been worked out are follows as, Anti-inflammatory activity, antihelminthic activity, antistrees and anti allergic, antimicrobial activity, antioxidant activity, antifungal activity, antitumor activity, antidiaaraheal activity, analgesic and antipyretic activity, allelopathic activity, hypolipidomeic activity, wound healing, immunomodulatory activity $[1-4,7]$.

\section{Conclusion}

However this is the short review article of the genus Ficus bengelensis of the Moraceae family. The genus is very well distributed and they have the long and the very well established
Indian mythological stories. The tree is the reserves of the many kinds of the metabolites the medical values and they have long been used from the remote time for the treatment of the many disorders by the tribal peoples. The tree is worshipped ethically and it needs the conservation for the many more photochemical and the pharmacological values evaluation.

\section{References}

1. (Ficus benghalensis) Germplasm Resources Information Network (GRIN).

2. (2016) Agricultural Research Service. United States Department of Agriculture.

3. Midya S, Brahmachary RL (1991) The Effect of Birds upon Germination of Banyan (Ficus bengalensis) Seeds. Journal of Tropical Ecology 7(4): 537-538.

4. "National Tree". Govt of India Official website. Archive.

5. (Ficusbenghalensis var. benghalensis) Ayurvedic Medical Plants of Srilanka. University of Ruhuna, Srilanka.

6. ST Gopukumar, PK Praseetha (2015) Ficus benghalensis Linn the Sacred Indian Medicinal Tree with Potent Pharmacological Remedies. Int J Pharm Sci Rev Res 32(1): 223-227.

7. (Ficus benghalensis Linnaeus) The Plant List.

8. Bar Ness YD (2010) The World's Largest Trees? Cataloguing India's Giant Banyans. Outreach Ecology.

9. Simoons FJ (1998) Plants of Life, Plants of Death. University of Wisconsin Press, USA.

10. Chisholm, Hugh, Ed. (1911) Fig. Encyclopædia Britannica (11 ${ }^{\text {th }}$ edn), Cambridge University Press, India.

Your next submission with Juniper Publishers
will reach you the below assets
- Quality Editorial service
- Swift Peer Review
- Reprints availability
- E-prints Service
- Manuscript Podcast for convenient understanding
- Global attainment for your research
- Manuscript accessibility in different formats
( Pdf, E-pub, Full Text, Audio)
- Unceasing customer service
Track the below URL for one-step submission
https://juniperpublishers.com/online-submission.php

